\title{
Proliferation-related Expression of p19/nm23 Nucleoside Diphosphate Kinase
}

\author{
D. Keim, ${ }^{\star}$ N. Hailat, ${ }^{\star}$ R. Melhem, ${ }^{\star}$ X. X. Zhu, ${ }^{\star}$ I. Lascu, ${ }^{\star}$ M. Veron, ${ }^{\ddagger}$ J. Strahler, ${ }^{\star}$ \\ and S. M. Hanash* \\ *University of Michigan Medical School, Department of Pediatric Hematology, Ann Arbor, Michigan 48109; \\ and ${ }^{\ddagger}$ Unite de Biochimie Cellulaire, Institut Pasteur, Paris, France
}

\section{Abstract}

High level expression of the nm23-H1 gene, which encodes for a nucleoside diphosphate kinase, has been found to correlate with diminished metastasis in some tumors but not in others. We have previously identified the protein product of the nm23H1 gene in two-dimensional electrophoretic gels and have designated it p19/nm23. In neuroblastoma, higher levels of p19/ $\mathrm{nm} 23$, which are associated with amplification of the $\mathrm{N}$-myc oncogene, large tumor mass, and metastasis, were observed in advanced stage tumors compared with limited stage disease. Because of the variable expression of $\mathrm{nm} 23-\mathrm{H1}$ in different tumors, we have investigated the relationship between amounts of the protein and cell proliferation. The levels of $\mathrm{p} 19 / \mathrm{nm} 23$ were compared between resting and mitotically stimulated normal human PBLs and in leukemia cells. The amount of p19/ nm23 increased in normal lymphocytes in response to mitotic stimulation and paralleled the increase in DNA synthesis. In leukemia cells obtained from patients with different subtypes of acute leukemia, p19/nm23 levels were also increased relative to resting normal lymphocytes. Treatment of mitotically stimulated lymphocytes with cyclosporin, which inhibits prolifera-

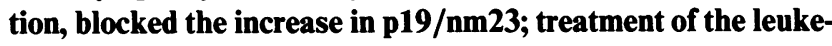
mia cell line HL-60 with dimethylsulfoxide, which induces terminal differentiation, resulted in diminished levels of $\mathrm{p} 19 / \mathrm{nm} 23$. Our data therefore provide evidence that nm23-H1 expression is related to cell proliferative activity. (J. Clin. Invest. 1992. 89:919-924.) Key words: lymphocytes • metastasis • proliferation

\section{Introduction}

The factors responsible for tumor proliferation and spread to distant sites remain ill defined. The gene $\mathrm{nm} 23-\mathrm{H} 1$ has been proposed as a candidate tumor metastasis suppressor on the basis of initial findings in certain tumors (1). In human infiltrating ductal breast carcinomas and in model systems of rodent metastasis, nm23 RNA levels were lower in highly metastatic cells than in tumor cells of low metastatic potential $(2,3)$. Primary tumors that expressed high levels of nm 23 mRNA, as determined by hybridization to murine nm 23 cDNA, were associated with a relatively favorable prognosis relative to similar tumors with low levels of nm23 mRNA (4). Transfection of a murine $\mathrm{nm} 23$ expression construct into highly metastatic

Address correspondence to S. M. Hanash, University of Michigan, R4451 Kresge I, Box 0510, Ann Arbor, MI 48109-0510.

Received for publication 9 July 1991 and in revised form 19 September 1991.

J. Clin. Invest.

(c) The American Society for Clinical Investigation, Inc.

0021-9738/92/03/0919/06 \$2.00

Volume 89, March 1992, 919-924
K-1735 TK murine melanoma cells resulted in reduced incidence of primary tumor formation, reduced tumor metastatic potential, and altered responses to the cytokine transforming growth factor $\beta_{1}(5)$. In contrast to these results, nm23 expression, as determined by Northern blot analysis, was reported to be increased in colonic neoplasms relative to morphologically normal colon mucosa, with no association demonstrated between expression and metastatic potential (6). Furthermore, we have observed that the protein product of $\mathrm{nm} 23-\mathrm{H} 1$ occurs in greater amounts in advanced neuroblastoma tumors that are associated with $\mathrm{N}-m y c$ oncogene amplification and metastasis than in limited-stage tumors with a single copy of the N-myc gene (7).

In our previous studies, we initially identified the protein product of the nm23-H1 gene in two-dimensional electrophoretic gels of neuroblastoma cell proteins and designated it p19/ $\mathrm{nm} 23$ (7). We also previously detected this polypeptide in a variety of human cell lines, including lymphoid, myeloid, rhabdoid, colon, breast, and neural derived (8). The occurrence of $\mathrm{p} 19 / \mathrm{nm} 23$ was not limited to malignant cell lines and tumors, since it was present in reduced amounts in unstimulated normal PBMCs. The mol wt of $\mathrm{p} 19 / \mathrm{nm} 23$ was estimated to be 19,000 , based on the migration in two-dimensional gels of unmodified, neighboring polypeptides for which the full amino acid sequence is known. Three $\mathrm{p} 19 / \mathrm{nm} 23$ internal peptides, which we sequenced, matched exactly the deduced sequence of $\mathrm{nm} 23-\mathrm{H} 1$ (7).

$\mathrm{nm} 23-\mathrm{H} 1$ is highly homologous to a Dictyostelium discoideum nucleoside diphosphate (NDP) ${ }^{1}$ kinase (9) and to the Drosophila abnormal wing discs (awd) gene product (10) and is identical to human NDP kinase A (11). Functional association of NDP kinase with G-proteins or Ras has been described (12, 13) and NDP kinase activity copurifies with ribonucleotide reductase, a key enzyme of deoxyribonucleotide synthesis (14). Thus, $\mathrm{nm} 23-\mathrm{H} 1$ could play a role in signal transduction or in DNA synthesis. In view of the identified function of $\mathrm{nm} 23-\mathrm{H} 1$ and of its variable expression in tumors, we have examined the relationship between levels of $\mathrm{p} 19 / \mathrm{nm} 23$ protein and cell proliferation. Because lymphoid cells can be manipulated with respect to their proliferative activity, they were relied on to determine the relationship between $\mathrm{p} 19 / \mathrm{nm} 23$ levels and normal and malignant cell proliferation.

\section{Methods}

Sources of cells. Normal lymphocytes were isolated from peripheral blood of healthy volunteers by Ficoll-Hypaque gradient centrifugation and grown in RPMI 1640 medium supplemented with $10 \%$ FCS, $0.8 \%$ L-glutamine $(29.2 \mu \mathrm{g} / \mathrm{ml})$, and $1 \%$ of penicillin/streptomycin $(10,000$

1. Abbreviations used in this paper: $\mathrm{ALL}$, acute lymphocytic leukemia; ANLL, acute nonlymphocytic leukemia; 2-D, two-dimensional; NDP, nucleoside diphosphate. 
$\mathrm{IU} / \mathrm{ml}$ and $10 \mathrm{mg} / \mathrm{ml}$, respectively). For mitotic stimulation, cells were incubated in the presence PHA $(1 \mu \mathrm{g} / \mathrm{ml})$, then harvested at specific time points, washed three times with PBS, and centrifuged into pellets.

The primary source of leukemic cells was a group of 177 patients with acute leukemia studied at the time of initial diagnosis. All patients were advised of procedures and attendant risks in accordance with the institutional guidelines, and all gave informed consent. There were 21 patients with T cell acute lymphocytic leukemia (ALL), 140 with pre B-cell ALL, and 16 with acute nonlymphocytic leukemia (ANLL). The leukemic cells constituted $85 \%$ or more of the total mononuclear cells in most preparations. The specific diagnosis was made on the basis of morphological features and histochemical staining of cells with peroxidase, esterase, and Sudan black; rosetting with sheep erythrocytes; and reactivity with a battery of $\mathrm{mAb}$ 's (15). Fresh leukemic cell pellets were prepared as for PBLs.

HL-60 human myeloid leukemia cells were treated with DMSO (1.3\%), then incubated for $40 \mathrm{~h}$ and harvested in a manner similar to above. As a control, HL-60 cells not treated with DMSO were incubated and harvested in an identical fashion.

Two-dimensional (2-D) PAGE. Cell pellets were solubilized by addition of lysis buffer consisting of (per liter) $8 \mathrm{M}$ urea, $20 \mathrm{ml}$ of Nonidet P-40 surfactant, $20 \mathrm{ml}$ of ampholytes (pH 3.5-10), $20 \mathrm{ml}$ of 2-mercaptoethanol, and $0.2 \mathrm{mM}$ of PMSF in distilled deionized water. 2-D PAGE, silver staining, spot detection, and quantification were performed as previously described (7).

Identity of $\mathrm{p} 19 / \mathrm{nm} 23$ by Western blot. The identity of $\mathrm{p} 19 / \mathrm{nm} 23$ as NDP kinase A was determined by Western blotting of two-dimensional gels as previously described (7) using an antiserum raised against NDPkinase A (11).

Proliferation assay. Normal PBLs treated with PHA as above were labeled with $\left[{ }^{3} \mathrm{H}\right]$ thymidine for $4 \mathrm{~h}$, using $1 \mu \mathrm{Ci} / 50,000$ cells per well, before harvesting at designated times. DNA content was performed using standard propidium iodide staining techniques (16).

Flow cytometry. Normal PBLs were divided into two aliquots: one was incubated for the stated time in RPMI 1640 supplemented with 5\% FCS without PHA, and the second was stimulated with $1 \mu \mathrm{g} / \mathrm{ml}$ PHA. After harvesting and washing with PBS, the cells were fixed with $0.5 \%$ paraformaldehyde for $15 \mathrm{~min}$, permeabilized with $0.1 \%$ Triton X-100 in PBS at room temperature for $10 \mathrm{~min}$, and then washed twice with PBS. Antibody $(1: 1,000)$ against human erythrocyte NDP kinase A (11) was added for $4 \mathrm{~h}$ at $4^{\circ} \mathrm{C}$. The cells were subsequently washed three times with cold PBS, the final wash containing PBS with $1 \%$ goat serum. Goat anti-rabbit FITC-conjugated antibody (Sigma Chemical Co., St. Louis, MO) was added at 1:60 for $1 \mathrm{~h}$, then the cells were washed three times with cold PBS before flow cytometry. Flow cytometric analysis of 5,000 cells was performed on a C cell sorter (Epic Inc. New York, NY).

\section{Results}

Relationship between p19/nm23 levels and cell proliferation. Freshly isolated normal PBLs were mitotically stimulated with PHA and their cellular proteins analyzed by 2-D PAGE to determine the relationship between cell proliferation and p19/ nm23 levels. Cellular $\left[{ }^{3} \mathrm{H}\right]$ thymidine uptake and flow cytometric analysis of cell DNA content were also determined as measures of proliferative activity. After PHA stimulation, p19/ $\mathrm{nm} 23$ increased from a faint to a prominent spot in silver-stained gels (Fig. 1, Table I). In time course experiments, quantitative analysis indicated that the change in integrated
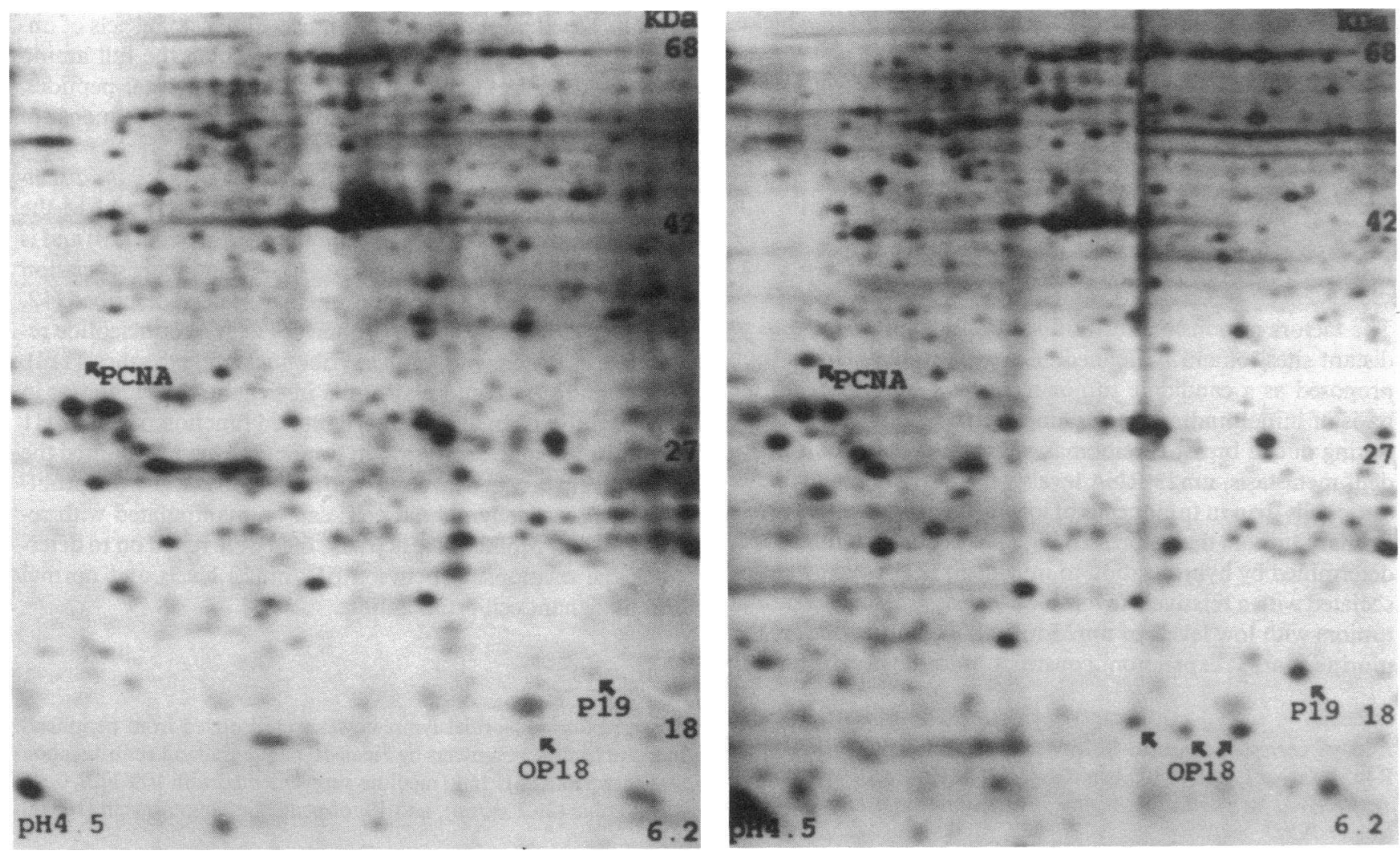

Figure 1. 2-D PAGE polypeptide patterns exhibiting a difference in the relative amount of $\mathrm{p} 19 / \mathrm{nm} 23$ before (left) and after (right) stimulation of normal PBLs with PHA. Arrows point to the location of $\mathrm{p} 19 / \mathrm{nm} 23$ and of two known proliferation markers: proliferation cell nuclear antigen (PCNA ) and Op18 $(15,25)$. The relative integrated intensities of $\mathrm{p} 19 / \mathrm{nm} 23$ in the left and right panels are, respectively, 0.23 and 1.79 . The $\mathrm{pH}$ is indicated on the horizontal axis and molecular weight is indicated on the vertical axis. 
Table I. Comparison of Levels of p19/nm23 as Determined by 2-D PAGE in Different Cell Populations

\begin{tabular}{|c|c|c|c|c|}
\hline Cell type & $n$ & $\begin{array}{c}\mathrm{p} 19 / \mathrm{nm} 23 \\
\text { integrated } \\
\text { intensity }\end{array}$ & SD & $P$ \\
\hline Unstimulated lymphocytes & 6 & 0.63 & 0.22 & \\
\hline Stimulated lymphocytes & 6 & 2.03 & 0.23 & 0.0001 \\
\hline B-cell clones & 28 & 1.75 & 0.45 & 0.01 \\
\hline T ALL & 21 & 1.51 & 0.92 & 0.05 \\
\hline pre-B ALL & 140 & 1.28 & 0.71 & 0.04 \\
\hline ANLL & 16 & 2.47 & 1.15 & 0.002 \\
\hline
\end{tabular}

$P$, statistical significance for comparisons with unstimulated lymphocytes. $n$, number of samples.

intensity of $\mathrm{p} 19 / \mathrm{nm} 23$ paralleled the increase in $\left[{ }^{3} \mathrm{H}\right]$ thymidine uptake and the increase in percentage of cells in the $S$ phase (Fig. 2). An increase in $\left[{ }^{35}\right.$ S] methionine labeling of $\mathrm{p} 19 / \mathrm{nm} 23$ was detected by autoradiography, beginning at $18 \mathrm{~h}$ after PHA stimulation, suggesting that the change observed in $\mathrm{p} 19 / \mathrm{nm} 23$ protein level is due to an increase in newly synthesized p19/ nm23 (data not shown). Pulse-chase experiments indicated that $\mathrm{p} 19 / \mathrm{nm} 23$ is a relatively stable protein in proliferating normal lymphocytes, with an approximate $t_{1 / 2}$ of $20 \mathrm{~h}$ (data not shown), in agreement with the reported high stability of the protein in human erythrocytes (17). Maximum $\mathrm{p} 19 / \mathrm{nm} 23$ protein accumulation, as observed in silver-stained gels, occurred at $72 \mathrm{~h}$ (Fig. 2). In a series of six experiments, after $3 \mathrm{~d}$ of PHA treatment, there was a greater than threefold increase in mean integrated intensity of $\mathrm{p} 19 / \mathrm{nm} 23$ in silver-stained gels relative to unstimulated lymphocytes (Table I, means $=2.03$ vs. 0.63 , respectively; $P=0.0001$ ), corresponding to an approximately sixfold increase in amount of protein, based on previous quantitative protein studies using 2-D gels (18). Similar increases in p19/nm23 were observed after stimulation of PBLs with an anti-CD3 antibody (OKT3, data not shown).

To further determine the extent of change in $\mathrm{p} 19 / \mathrm{nm} 23$ levels in maximally proliferating lymphoid cells in culture, we quantified the level of $\mathrm{p} 19 / \mathrm{nm} 23$, by 2-D PAGE, in proliferating Epstein-Barr virus-transformed $B$ cells harvested during the logarithmic growth phase. The mean integrated intensity of 28 single cell-derived $B$ cell clones was equivalent to the mean observed for PHA-stimulated T cells (Table I), providing evidence that the increase in the level of $\mathrm{p} 19 / \mathrm{nm} 23$ with proliferation is not limited to any one subtype of lymphocytes. We also determined the effect of inhibiting lymphoid proliferation with cyclosporin (19) on $\mathrm{p} 19 / \mathrm{nm} 23$ levels. In contrast to an increase in p19/nm 23 observed after treatment of PBLs with OKT3 alone, addition of cyclosporin prevented any increase in p19/ $\mathrm{nm} 23$ levels in response to OKT3 treatment.

Reactivity of p19/nm23 with an antibody to NDP kinase A. Western blot analysis of proteins from resting and proliferating normal lymphocytes and from leukemic cells separated by 2-D PAGE was performed using a polyclonal rabbit antiserum against the human NDP kinase A (11). This antibody preparation reacted exclusively with one polypeptide spot that corresponded to $\mathrm{p} 19 / \mathrm{nm} 23$, further confirming the identity of $\mathrm{p} 19 /$ $\mathrm{nm} 23$ and also suggesting absence of modified forms with altered charge and/or mol wt in any of the cell types analyzed.
Thus, the relatively higher estimated mol wt of $\mathrm{p} 19 / \mathrm{nm} 23$, compared with the calculated mol wt of the protein product of $\mathrm{nm} 23-\mathrm{H} 1$, is likely a characteristic of the protein resulting from its extent of binding SDS.

Flow cytometric analysis of NDP kinase A. Flow cytometric analysis of resting and mitotically stimulated normal PBLs was also undertaken using the antiserum against NDP kinase $A$ (11). While there was no significant difference in fluorescence intensity between normal PBLs before and after PHA treatment for $20 \mathrm{~h}$, an increased percentage of cells with significantly greater fluorescence intensity was observed after $48 \mathrm{~h}$ of PHA treatment (Fig. 3). A shift in fluorescence intensity from a mean of 30.8 for untreated cells to 48.0 for cells treated with PHA for $48 \mathrm{~h}$ was determined after conversion to specific linear fluorescence values (20). The timing of increased fluorescence is consistent with the increase in $\mathrm{p} 19 / \mathrm{nm} 23$ levels observed in time course studies by 2-D PAGE.

p19/nm23 phosphorylation status. NDP kinase is transiently phosphorylated at its active site on a histidine residue as part of its catalytic mechanism $(11,21)$. To determine whether p19/nm23 additionally undergoes stable phosphorylation at a different site, metabolic labeling of lymphoid cells in phosphate-poor media supplemented with ${ }^{32} \mathrm{P}$-labeled inorganic phosphate or with $\left[{ }^{32} \mathrm{P}\right] \gamma$-ATP was undertaken. Autoradiographic analysis did not reveal a labeled spot in the position of p19/nm23. Furthermore, Western blot analysis with an antibody to NDP kinase A indicated lack of reactivity with a neighboring spot that could represent a phosphorylated form of $\mathrm{p} 19 /$ $\mathrm{nm} 23$.

p19/nm23 levels in leukemia cells. We have compared the amount of p19/nm23 in normal lymphocytes and in acute leukemia cells. Levels of p19/nm23 in ALL samples obtained

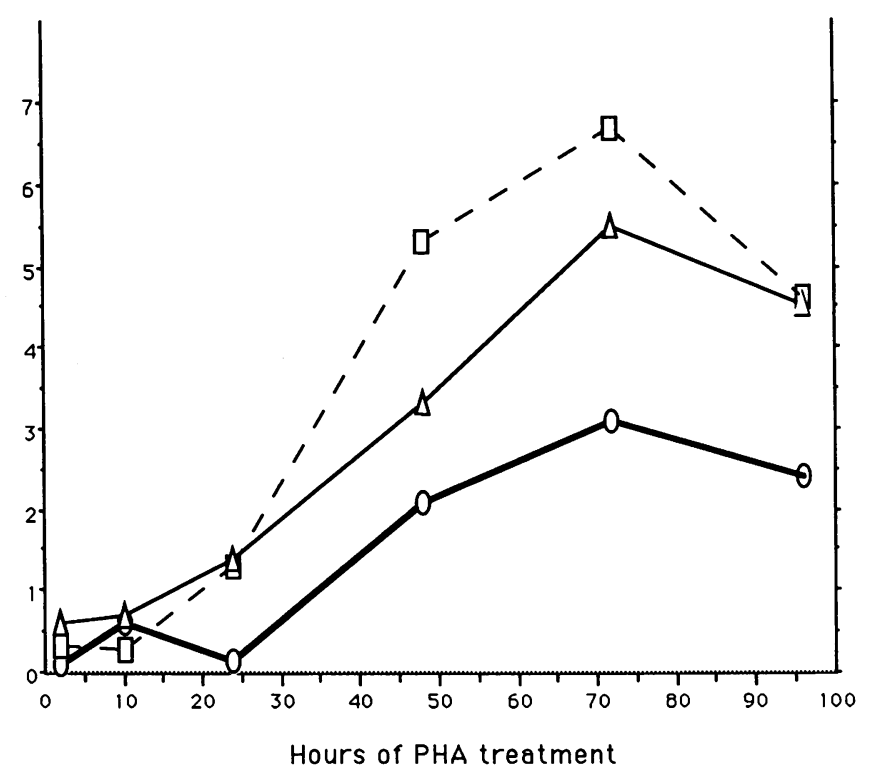

Figure 2. Time course of change in $\mathrm{p} 19 / \mathrm{nm} 23$ protein relative integrated intensity in silver-stained gels, in $\left[{ }^{3} \mathrm{H}\right]$ thymidine uptake, and in percentage of cells in $\mathrm{S}$ phase for normal lymphocytes stimulated with PHA $(1 \mathrm{mg} / \mathrm{ml})$. Maximum levels of $\mathrm{p} 19 / \mathrm{nm} 23$ coincided with peaks of $\left[{ }^{3} \mathrm{H}\right]$ thymidine uptake and of percentage of cells in $\mathrm{S}$ phase. $\circ$, Percentage of cells in S phase $(\% \times 10) ; \square,\left[{ }^{3} \mathrm{H}\right]$ thymidine counts $(\times 10,000 \mathrm{cpm}) ; \Delta, \mathrm{p} 19 / \mathrm{nm} 23$ relative integrated intensity. 

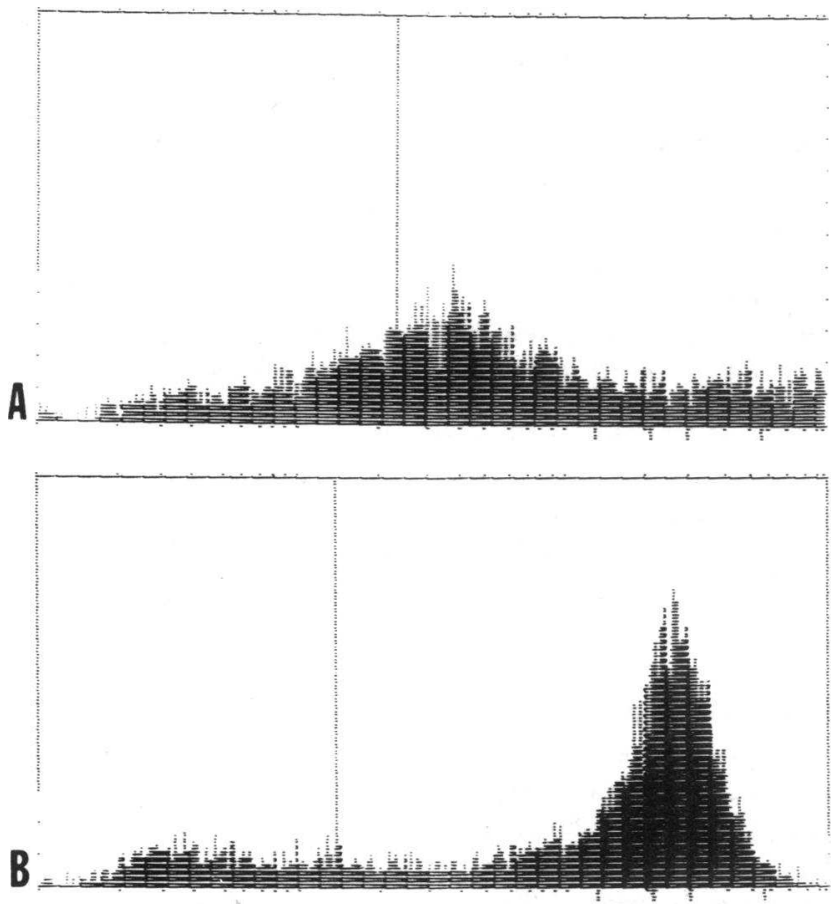

Figure 3. Flow cytometric analysis of resting normal PBLs $(A)$ and of normal PBLs treated with $1 \mu \mathrm{g} / \mathrm{ml}$ of PHA for $48 \mathrm{~h}(B)$, using an antibody to NDP kinase A (11). The $x$ and $y$ axes represent log fluorescence and cell number, respectively. Vertical cursor in each figure marks the upper limit of nonspecific staining as determined by treatment of cells with secondary FITC antibody only. An increase in fluorescence intensity is observed in PHA-treated cells. Cell proliferation was confirmed by DNA analysis and by $\left[{ }^{3} \mathrm{H}\right]$ thymidine incorporation.

from patients at the time of diagnosis were statistically significantly higher than in unstimulated normal PBLs and corresponded to the levels observed in nonmalignant proliferating lymphoid cells we have studied (Table I). There was no signifi- cant difference in the amount of $\mathrm{p} 19 / \mathrm{nm} 23$ between the two major subtypes of ALL, namely, T and pre-B ALL. The mean p19/nm23 level in the ANLL group, represented predominantly by leukemias of myeloid origin, was significantly greater than that for ALL. We have examined the relationship between p19/nm23 levels and the mass of leukemic cells, as measured by the total peripheral white blood cell count at the time of diagnosis. There was no significant relationship between the level of p19/nm23 and the white blood cell count for the total group of acute leukemia samples or for each of the three subgroups studied, suggesting that the tumor load in acute leukemia is not related to the level of $\mathrm{p} 19 / \mathrm{nm} 23$.

The HL-60 myeloid leukemia cell line exhibited high levels of p19/nm23. Treatment of HL-60 cells with DMSO or phorbol-12-myristate-13-acetate (PMA) is known to result in terminal differentiation to morphologically mature cells $(22,23)$. In two separate experiments in which HL-60 cells were treated with DMSO for $40 \mathrm{~h}$, we observed a decrease in the amount of $\mathrm{p} 19 / \mathrm{nm} 23$ as well as in the amount of other proliferation-related polypeptides that we have identified in 2-D gels (Fig. 4). Similar results were obtained when HL-60 cells were treated with PMA (data not shown).

\section{Discussion}

The increase in $\mathrm{p} 19 / \mathrm{nm} 23$ in response to mitogenic stimulation of lymphocytes, which parallels the increase in $\left[{ }^{3} \mathrm{H}\right]-$ thymidine uptake and in the percentage of cells in S phase, together with the decrease in $\mathrm{p} 19 / \mathrm{nm} 23$ observed after treatment of HL-60 with DMSO and the lack of increase in p19/ $\mathrm{nm} 23$ in PHA-treated lymphocytes in the presence of cyclosporin, indicates that the level of $\mathrm{p} 19 / \mathrm{nm} 23$ changes in a manner related to proliferative activity. The change in the level of p19/nm23 in response to PHA occurred as a relatively late event, in a manner suggestive of a potential role for this protein in late $G_{1}$ and $S$ phases of the cell cycle. Levels of p19/nm23 observed in ALL were equivalent to the levels observed in nonmalignant proliferating $T$ and $B$ cells, suggesting a similarity in

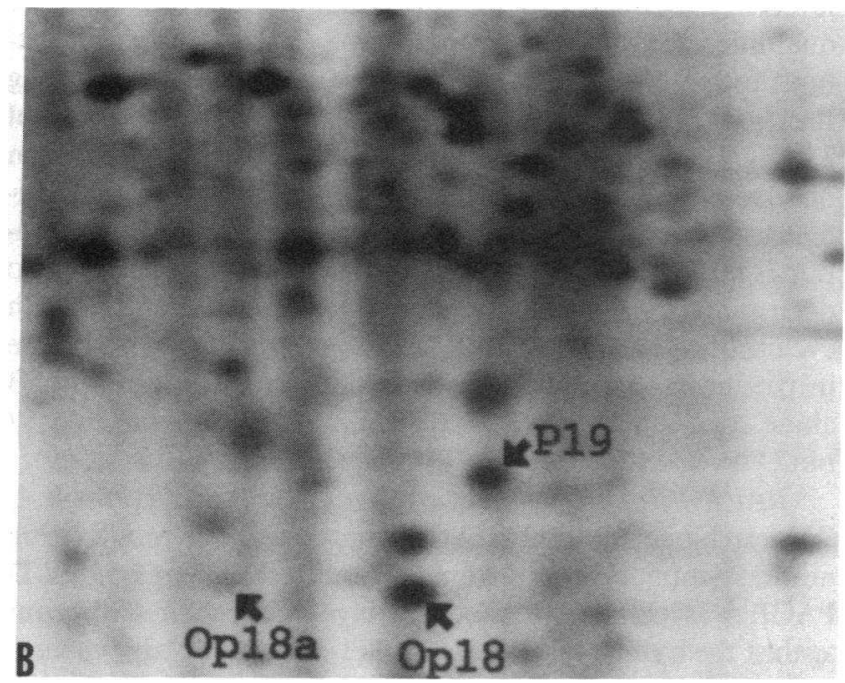

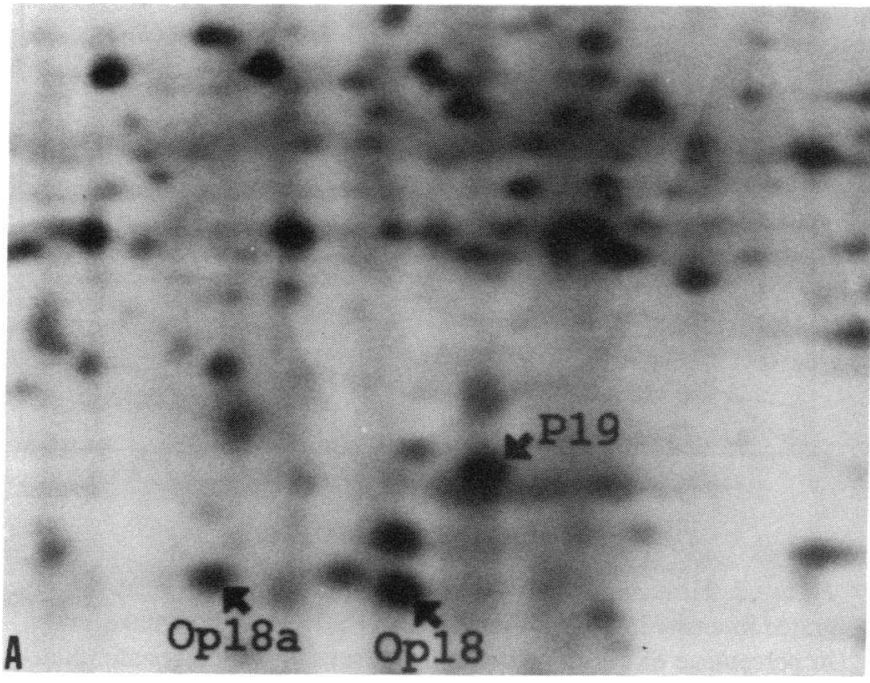

Figure 4. Change in the amount of p19/nm23 after treatment of HL-60 cells with DMSO $(1.3 \%)$ for $40 \mathrm{~h}$. $(A)$ pattern of untreated of HL-60 cells; (B) pattern of HL-60 cells treated with DMSO. Arrow marks p19/nm23. The relative integrated intensities for p19/nm23 in $A$ and $B$, respectively, are 5.41 and 2.19. Another proliferation polypeptide in the same region of the gel, Op18 (25), is marked as a reference. 
the expression of this protein between malignant and nonmalignant proliferating lymphoid cells. However, the p19/nm23 levels measured by 2-D PAGE reflect total amount of protein. Differences in intracellular distribution may occur among resting normal lymphocytes, proliferating normal lymphocytes, and leukemic cells.

Recently, a second distinct human nm23 gene, designated $\mathrm{nm} 23-\mathrm{H} 2$, has been identified, which encodes for a peptide that is $88 \%$ identical to that of $\mathrm{nm} 23-\mathrm{H} 1$ (24). Levels of $\mathrm{nm} 23-\mathrm{H} 2$ were not reduced in highly metastatic breast tumors to the same extent as nm23-H1 (24). Gene nm23-H2 has been found to be identical to human erythrocyte NDP-kinase B (11), with a predicted $\mathrm{pI}$ of $\sim 9$. On the basis of its $\mathrm{pI}$, the protein product of $\mathrm{nm} 23-\mathrm{H} 2$ would be expected to migrate beyond the usual limits of carrier ampholyte-based 2-D gels and not to the position of $\mathrm{p} 19 / \mathrm{nm} 23$. Thus, the sequence data we have generated, together with the $\mathrm{pI}$ of $\mathrm{p} 19 / \mathrm{nm} 23$ and its exclusive reactivity with an antibody to human NDP kinase $\mathrm{A}$, clearly indicate that $\mathrm{p} 19 / \mathrm{nm} 23$ is identical with $\mathrm{nm} 23-\mathrm{H} 1$ and not $\mathrm{nm} 23-\mathrm{H} 2$.

Several proteins other than p19/nm 23 are known to be expressed in a proliferation-related manner in late $G_{1}$ and $S$ phase. Two that we have identified and investigated by 2-D PAGE are proliferating cell nuclear antigen, the auxiliary protein of DNA polymerase $\delta$ that is required for DNA synthesis and for cell proliferation, and Op18, a major phosphoprotein (Fig. 1) $(15,25)$. Both are present in greater amounts in normal proliferating lymphocytes than in resting lymphocytes, and both are present in equal or greater amounts in leukemic cells than in normal proliferating lymphocytes. Our studies to date indicate that increased levels of $\mathrm{p} 19 / \mathrm{nm} 23$ observed in proliferating cells are also associated with increased proliferating cell nuclear antigen and Op18 levels.

The proliferation-related increase in $\mathrm{p} 19 / \mathrm{nm} 23$ demonstrated in this study is of interest in relation to the proposed role for $\mathrm{nm} 23$ as a tumor metastasis suppressor gene (1). In a separate study of neuroblastoma tumors, we observed statistically significantly higher levels of p19/nm23 in tumors from patients with advanced-stage disease than in tumors of limitedstage disease (7). A highly significant correlation was also observed between $\mathrm{p} 19 / \mathrm{nm} 23$ levels and amplification of the $\mathrm{N}$ $m y c$ oncogene, a feature associated with tumor progression and spread (26). Thus, in our studies of $\mathrm{p} 19 / \mathrm{nm} 23$, proliferating lymphoid cells and advanced-stage neuroblastoma tumor cells exhibited higher levels of the protein than did resting lymphocytes and limited-stage neuroblastoma tumors, respectively. These observations would suggest involvement of NDP kinase/ p19/nm23 in normal and malignant proliferation that is distinct from its proposed role as a tumor metastasis suppressor.

It is of interest that the protein products of two other genes that play a role in tumor suppression, namely, p53 and RB1, have been found to undergo modification or to increase in amount in normal cells that have been induced to proliferate (27-29). Mutated forms of p53 and RB1 are associated with malignant proliferation $(30,31)$. To date there has been no evidence for mutant forms of $\mathrm{nm} 23-\mathrm{H} 1$. Carbone et al. (32) have sequenced the full open reading frame for $n m 23$ in 10 small-cell lung cancer lines and have not found coding mutations. Our studies of neuroblastoma and leukemia indicate absence of a mutation in the $\mathrm{nm} 23-\mathrm{H} 1$ gene that would have altered the $\mathrm{pI}$ or molecular weight of the protein product as determined by 2-D PAGE. On the basis of our findings, the relationship between $\mathrm{nm} 23-\mathrm{H} 1$ levels and proliferative activity should be taken into consideration to allow a critical assessment of the role of $\mathrm{nm} 23-\mathrm{H} 1$ in tumor cell metastasis.

\section{Acknowledgment}

We thank D. Hodge and R. Kuick for assistance with gel and data analysis.

This work was supported in part by grants CA-26803 and CA32146 (S. M. Hanash) from the National Cancer Institute, Department of Health and Human Services, and by grants CNRS UA1129, and Association de Recherche contre le Cancer ARC 6438 (M. Veron). I. Lascu was a recipient of a fellowship from the Ligue Nationale Francaise contre le Cancer.

\section{References}

1. Rosengard, A. M., H. C. Krutsch, A. Shearn, J. R. Biggs, E. Barker, I. M. Margulies, C. R. King, L. A. Liotta, and P. S. Steeg. 1989. Reduced nm23/awd protein in tumor metastasis and aberrant Drosophila development. Nature (Lond.). 342:177-180.

2. Steeg, P. S., G. Bevilacqua, L. Kopper, U. P. Thorgeirsson, J. E. Talmadge, L. A. Liotta, and M. E. Sobel. 1988. Evidence for a novel gene associated with low tumor metastatic potential. J. Natl. Cancer Inst. 80:200-204.

3. Bevilacqua, G., M. E. Sobel, L. A. Liotta, and P. S. Steeg. Association of low nm23 RNA levels in human primary infiltrating ductal breast carcinomas with lymph node involvement and other histopathological indicators of high metastatic potential. 1989. Cancer Res. 49:5185-5190.

4. Hennessy, C., J. A. Henry, F. E. B. May, B. R. Westley, B. Angus, and T. W. J. Lennard. 1991. Expression of the antimetastatic gene nm23 in human breast cancer: an association with good prognosis. J. Natl. Cancer Inst. 83:281285.

5. Leone, A., U. Flatow, C. R. King, M. A. Sandeen, I. M. K. Margulies, L. A. Liotta, and P. S. Steeg. 1991. Reduced tumor incidence, metastatic potential, and cytokine responsiveness of nm23-transfected melanoma cells. Cell. 65:25-35.

6. Haut, M., P. S. Steeg, J. K. V. Willson, and S. D. Markowitz. 1991. Induction of nm23 gene expression in human colonic neoplasms and equal expression in colon tumors of high and low metastatic potential. J. Natl. Cancer Inst. 83:712-716.

7. Hailat, N., D. R. Keim, R. F. Melhem, X. X. Zhu, C. Eckerskorn, G. M. Brodeur, C. P. Reynolds, R. C. Seeger, F. Lottspeich, J. R. Strahler, and S. M. Hanash. 1991. High levels of $\mathrm{p} 19 / \mathrm{nm} 23$ protein in neuroblastoma are associated with advanced stage disease and with $\mathrm{N}-m y c$ gene amplification. J. Clin. Invest. 88: 341-345.

8. Hanash, S. M., M. Gagnon, R. C. Seeger, and L. Baier. 1985. Analysis of neuroblastoma cell proteins using two-dimensional electrophoresis. In Advances in Neuroblastoma Research: Progress in Clinical and Biological Research. A. Evans E., G. J. D'Angio and R. C. Seeger, editors. Alan R. Liss, Inc., New York. 261-268.

9. Wallet, V., R. Mutzel, H. Troll, O. Barzu, B. Wurster, M. Veron, and M.-L. Lacombe. 1990. Dictyostelium nucleoside diphosphate kinase highly homologous to $\mathrm{nm} 23$ and awd proteins involved in mammalian tumor metastasis and Drosophila development. J. Natl. Cancer Inst. 82:1199-1202.

10. Biggs, J., E. Hersperger, P. S. Steeg, L. A. Liotta, and A. Shearn. 1990. A Drosophila gene that is homologous to a mammalian gene associated with tumor metastasis codes for a nucleoside diphosphate kinase. Cell. 63:933-940.

11. Gilles, A.-M., E. Presecan, A. Vonica, and I. Lascu. 1991. Nucleoside diphosphate kinase from human erythrocytes: structural characterization of the two polypeptide chains responsible for heterogeneity of the hexameric enzyme. $J$. Biol. Chem. 266:8784-8789.

12. Ohtsuki, K., T. Ikeuchi, and M. Yokoyama. 1986. Characterization of nucleoside-diphosphate kinase-associated guanine nucleotide-binding proteins from HeLa S3 cells. Biochim. Biophys. Acta. 882:322-330.

13. Kikkawa, S., K. Takahashi, K. Takahashi, N. Shimada, M. Ui, N. Kimura, and T. Katada. 1990. Conversion of GDP into GTP by nucleoside diphosphate kinase on the GTP-binding proteins. J. Biol. Chem. 265:21536-21540. Correction page: 1991. 266:12795.

14. von Dobeln, U. 1976. Nucleoside diphosphate kinase activity associated with ribonucleotide reductase. Biochem. Biophys. Res. Commun. 72:1160-1168.

15. Keim, D., N. Hailat, D. Hodge, and S. M. Hanash. 1990. Proliferating cell nuclear antigen expression in childhood acute leukemia. Blood. 76:985-990.

16. Vindelov, L. L., I. J. Christensen, and N. I. Nissen. 1983. Standardization of high resolution flow cytometric DNA analysis by the simultaneous use of chicken and trout red blood cells as internal standards. Cytometry. 3:328-331.

17. Agarwal, R. P., E. M. Scholar, K. C. Agarwal, and R. J. Parks. 1971. Identification and isolation on a large scale of guanylate kinase from human erythrocytes: effects of monophosphate nucleotides of purine analogs. Biochem. Pharmacol. 20:1341-1354. 
18. Kuick, R., S. M. Hanash, E. H. Y. Chu, and J. R. Strahler. 1987. A comparison of some adjustment techniques for use with quantitative spot data. Electrophoresis. 8:199-204.

19. Shevach, E. M. 1985. The effects of cyclosporin A on the immune system. Annu. Rev. Immunol. 3:397-423.

20. Muirhead, K. A., T. C. Schmitt, and A. R. Muirhead. 1983. Determination of linear fluorescence intensity from flow cytometric data accumulated with logarithmic amplifiers. Cytometry. 3:251-256.

21. Parks, R. E. J., and R. P. Agarwal. 1973. Nucleoside diphosphokinases. Enzymes. 8:307-334.

22. Huberman, E., and M. Callaham. 1979. Induction of terminal differentiation in human promyelocytic leukemia cells by tumor-promoting agents. Proc Natl. Acad. Sci. USA. 76:1293-1297.

23. Collins, S. J., F. W. Ruscetti, R. E. Gallagher, and R. C. Gallo. 1978. Terminal differentiation of human promyelocytic leukemia cells induced by dimethyl sulfoxide and other polar compounds. Proc. Natl. Acad. Sci. USA. 75:2458-2462.

24. Stahl, J. A., A. Leone, A. M. Rosengard, L. Porter, C. R. King, and P. S. Steeg. 1991. Identification of a second human $\mathrm{nm} 23$ gene, $\mathrm{nm} 23-\mathrm{H} 2$. Cancer Res. 51:445-449.

25. Hanash, S. M., J. R. Strahler, R. Kuick, E. H. Y. Chu, and D. Nichols. 1988. Identification of a polypeptide associated with the malignant phenotype in acute leukemia. J. Biol. Chem. 263:12813-12815.
26. Seeger, R. C., G. M. Bordeur, H. Sather, A. Dalton, S. E. Siegel, K. Y. Wong, and D. Hammond. 1985. Association of multiple copies of the N-myc oncogene with rapid progression of neuroblastoma. N. Engl. J. Med. 313:11111116.

27. Buchkovich, K., L. A. Duffy, and E. Harlow. 1989. The retinoblastoma protein is phosphorylated during specific phases of the cell cycle. Cell. 58:10971105 .

28. Coppola, J. A., B. A. Lewis, and M. D. Cole. 1990. Increased retinoblastoma gene expression is associated with late stages of differentiation in many different cell types. Oncogene. 5:1731-1733.

29. Reich, N. C., and A. J. Levine. 1984. Growth regulation of a cellular tumour antigen, p53, in nontransformed cells. Nature (Lond.). 308:199-201.

30. Benedict, W. F., X. Hong-Ji, and R. Takahashi. 1990. The retinoblastoma gene: its role in human malignancies. Cancer Invest. 8:535-540.

31. Stratton, M. R., S. Moss, W. Warren, H. Pattern, J. Clark, C. Fisher, C. D. Fletcher, A. Ball, M. Thomas, and B. A. Gusterson. 1990. Mutation of the p53 gene in human soft tissue sarcomas: association with abnormalities of the RB1 gene. Oncogene. 5:1297-1301.

32. Carbone, D., D. D'Amico, and J. Minna. 1991. Expression of DCC, $\mathrm{nm} 23$, and WT1 genes and alternative splicing of the putative wilms gene mRNA in small cell lung cancer cell lines. Proc. Am. Assoc. Cancer Res. 32:283. 